\title{
A Development of Mushroom Nugget Using Dragon Fruit Peel Additive (Hylocereus Polyrhizus) to Know the Organoleptic Products
}

\author{
Intan Ayu Puspita \\ Department of Public Health Sciences \\ University of Malang \\ Malang, Indonesia \\ Intanayupuspita21@gmail.com
}

\begin{abstract}
Indonesia has several nutritional problems related to the nutritional problem itself and over nutrition. Over nutritional problems will be risky for children to adulthood. Basic Health Research Data in 2013, Fast food innovation using oyster mushroom as the main ingredients that are processed as mushroom nuggets to facilitate the digestion. Mushrooms are plants that do not have chlorophyll and contain lots of protein. The author innovates by adding natural coloring agents using red dragon fruit peels, besides that the fruit is also rich of unsaturated fat that is important for health. The fiber in this fruit has a good benefit for digestion and regulating blood sugar levels. The purpose of developing the mushroom nugget using the natural coloring ingredients that is dragon fruit peel (Hylocereus Polyrhizus) as fast food that has healthy nutrition.
\end{abstract}

Keywords-Nugget, Dragon Fruit Peel, Hedonic.

\section{INTRODUCTION}

Indonesia has several nutritional problems, including under nutrition and overnutrition. More nutrition will lead to obesity in children until adulthood. Basic Health Research data in 2013, obesity habits in children aged 5-12 years up to $18.8 \%$ and provinces that have habits above the national average, namely in East Java (Kemenkes RI, 2013). Usually what affects obesity is genetic and environmental (Biro \& Wien, 2010: 18)

A fast food innovation using oyster mushroom as the base ingredient which is processed as mushroom nuggets to improve digestion. Mushrooms are plants that do not have chlorophyll and contain lots of protein. Oyster mushroom is one of the wood mushrooms that has a higher content than other wood mushrooms, the content of oyster mushrooms contains protein, fat, phosphorus, iron, thiamin and riboflavin higher than other types of mushrooms. Oyster mushrooms have a fast shelf life. (Arianto et al, 2009: 31-40). In addition, researchers chose white oyster mushrooms because the price is more affordable and easier to find. And researchers chose nuggets as a processed product because nuggets are easy and fast to manufacture, the ingredients for making nuggets are easy to find and nugget does not have a high risk of disease.

In addition to mushrooms, the authors also innovated by adding natural dyes using red dragon fruit skin. Indonesia is one of the most plant-rich countries because Indonesia has fertile soil and a tropical climate, making it easier for plants to thrive. Indonesia has tropical forests which contain 30,000 species of plants. 9,600 of them are plant species that have medicinal benefits, but only 200 species have been recognized and used as raw materials in the industrial sector for health (Prasetyono, 2012: 67)

Achievement of dragon fruit yields in Banyuwangi Regency 28,819 tons with an area of

1,152 ha in 2014. The yield increased compared to 2013, namely 16,631 tons with a plantation area of 678 ha. Dragon fruit production areas in Banyuwangi are in Bangorejo, Pesanggaran, Siliragung, Tegaldlimo and Purwoharjo Districts. Bangorejo contributes $39 \%$ of the total dragon fruit harvest in Banyuwangi or around 11,000 tonnes per ha with a land area of about 449 ha. Dragon fruit also fills the Banyuwangi traditional market, and is also transferred to other large areas, namely Malang, Surabaya, Bandung, Jakarta and Bali (Jayanti, 2015: 99-107).

In addition to the dragon fruit flesh which contains a lot of ingredients, the skin of the red dragon fruit is one of the waste products that is rarely used as a food processing ingredient. Dragon fruit skin is no less nutritious than the flesh. The skin of dragon fruit with red flesh (Hylocereus polyrhizus) has useful nutrients. The substances contained in the skin of red 
fleshy dragon fruit, namely in 100 grams of dragon fruit, have $60 \mathrm{kcal}$ calories, 0.53 protein, $11.5 \mathrm{sg}$ carbohydrates $0.71 \mathrm{~g}$ calcium $134.5 \mathrm{mg}, 87 \mathrm{mg}$ phosphorus, 0.65 iron $\mathrm{mg}$, vitamin $\mathrm{C}$ $9.4 \mathrm{mg}$, anthocyanins, antioxidants, phenols, flavonoids, protein, fat, water, carbohydrates, ash, pentacyclictriyepene taraxast 20ene and taraxast 12.20 (30) dien 3aol, and the water content is 90\% (Handayani and Rahmawati, 2012: 60). The special content of dragon fruit peel, namely fiber, which is $46.7 \%$ in the fiber content of dragon fruit cultivar is very high than some other types of bauh. Dietary fiber has several benefits that can control body weight (Santoso, 2011).

Because there are too many dragon fruit producers in Banyuwangi Regency and the skin is not used and has a high enough nutritional content, the authors innovated to make a mushroom nugget product using natural dyes, namely using a mixture of dragon fruit peels. The author chose mushroom nuggets because food ingredients are easy to find and mushrooms are low-fat plants, thus minimizing the risk of being overweight. Low fat intake can increase sufficient energy intake. According to Chazali (2010), white oyster mushrooms can be used as an alternative food especially for vegetarians and people with high cholesterol, besides white oyster mushrooms contain high lignocellulose fiber which is good for digestion. The author gives coloring with a mixture of red dragon fruit peel so that children are more interested in eating nuggets and hope that children's nutrition is sufficiently fulfilled by using natural ingredients.

\section{METHOD}

The design in this study uses research and development, namely the results of designs that are oriented towards developing or getting the results of a product. This design is one of the approaches used to get past the problem of creating an innovation and to develop the science of technology and art. This development uses a procedural model. Procedural is a descriptive model that is used to produce a particular product with a path of initial to final steps (Budiwanto, $201: 130$ ). The trial design of this research is research that uses expert validation and field trials, namely by carrying out a trial design to obtain data in order to perfect the mushroom nugget product with added red dragon fruit skin to be made. Data will be obtained from validation of experts in their fields and validation of no experts. The place for making nuggets is done in the kitchen of Kost Jalan Cimacan No. 4. Malang, Klojen District.

The field test to be able to see the initial product of this nugget will be read by three panelists who are experts in their fields, namely nutritionists / culinary experts, to see the shortcomings and weaknesses of a product that must be refined by researchers. The field test was carried out by untrained panelists by housewives who had children in the Jajag Village area RW 01, Banyuwangi Regency, Gambiran District, who were taken randomly. The subject of the trial was conducted by a Nutritionist 3 lecturer, a person who has the ability and sensitivity high enough to the product specifications that the researcher will make. Provides an understanding of the understanding and understanding of ways to assess organoleptics. And for non-expert panelists, it was carried out by housewives who had children in the Jajag Village area RW 01, Banyuwangi Regency, Gambiran District, with a total of 30 people taken randomly. Panelist mothers who are not trained are mothers who have not been trained to conduct organoleptic research.

This development research contains two types of data. First, there is qualitative data obtained by researchers from criticism and suggestions from the panelists of nutritionists regarding the product. Both quantitative data were obtained from an organoleptic questionnaire with an ordinal scale. Data collection used a questionnaire. This is a tool to make it easier for researchers to retrieve data. Researchers used a questionnaire with a hedonic scale. According to Samuel's (2005) theory, the hedonic scale reflects an instrument that presents directly from an experience based on pleasure (level of preference). The analysis of the hedonic scale will be converted into a numeric scale, then statistical analysis will be carried out. The hedonic scale used is very like (6), very like (5), like (4), somewhat like (3), neutral (2), dislike (1). Statistical data is used to describe a research result, but is not used to use a deeper and broader conclusion, therefore research analysis that does not use a sample can use descriptive statistics (Beni and Yana, 2018: 337). The qualitative organoleptic test results will be converted into quantitative form in a table by using the Friedman test using computer software. Specify Product Specifics. The composition of the product that has been produced in this study is in the form of fast food in the form of nuggets with the addition of red dragon fruit skin

TABle 1. Formula Product Composition TABLE

\begin{tabular}{|c|c|c|c|}
\hline \multirow[b]{2}{*}{$\begin{array}{l}\text { Bahan } \\
\text { Pangan }\end{array}$} & \multicolumn{3}{|c|}{ Formula Product Composition Table } \\
\hline & $\begin{array}{l}\text { Formula } 1 \\
\text { (F1) }\end{array}$ & $\begin{array}{l}\text { Formula } 2 \\
\text { (F2) }\end{array}$ & $\begin{array}{l}\text { Formula } \\
3 \text { (F3) }\end{array}$ \\
\hline $\begin{array}{l}\text { Red Dragon } \\
\text { Fruit Skin } \\
\text { Nugget } \\
\text { Formula }\end{array}$ & & 250 gram & $\begin{array}{l}375 \\
\text { gram }\end{array}$ \\
\hline $\begin{array}{l}\text { White } \\
\text { mushroom }\end{array}$ & 500 gram & 250 gram & $\begin{array}{l}125 \\
\text { gram }\end{array}$ \\
\hline White tofu & 100 gram & 100 gram & $\begin{array}{l}100 \\
\text { gram }\end{array}$ \\
\hline Shrimp & 20 gram & 20 gram & 20 gram \\
\hline onions & 50 gram & 50 gram & 50 gram \\
\hline Egg & 1 butir & 1 butir & 1 butir \\
\hline wheat flour & 200 gram & 200 gram & $\begin{array}{l}200 \\
\text { gram }\end{array}$ \\
\hline
\end{tabular}




\begin{tabular}{|l|l|l|l|}
\hline $\begin{array}{l}\text { bread } \\
\text { crumbs }\end{array}$ & 50 gram & 50 gram & 50 gram \\
\hline Salt & 15 gram & 15 gram & 15 gram \\
\hline pepper & 10 gram & 10 gram & 10 gram \\
\hline
\end{tabular}

Specifications are a real and definite description of what the product must obtain and describe the meaning of consumers. In this development research, the resulting product specifications are as follows:

a. Type of product: Fast food (Fast Food) Type of Fast Food: Mushroom nuggets and dragon fruit skin

b. Food ingredients: Oyster mushrooms, white tofu, wheat flour, shrimp, eggs, onions, dragon fruit skin

\section{Making Red Dragon Fruit Skin Nugget}

1. Prepare the ingredients in advance

2. In the first stage, prepare the materials and tools that will be used to simplify the manufacturing process

3. Peeling: Then separate some of the ingredients to be peeled using a knife including: separate the dragon fruit skin from the flesh, separate the potih oyster mushrooms from the roots at the bottom, separate the shrimp with the skin,

4. Washing: In this third stage, washing the ingredients with running water, wash the dragon fruit skin, then put it in the freezer so that it is not too slimy when blending, wash the shrimp until clean onions and tofu

5. Cutting: Next, cut some ingredients for easy weighing such as red dragon fruit skin, tofu, shrimp and mushrooms.

6. Weighing: Weighing is done using digital scales to maximize the amount that has been set. In this stage, all ingredients are weighed without exception.

7. Crushing: The process of crushing materials using a blander to make it smooth, soft and evenly mixed

8. Steaming: After that, the steaming process, after it is evenly mixed and divided into 3 formulas, pour it into a rectangular container with stainless steel for the steaming process. This steaming takes 45 minutes. Give the holes into the surface using a stick so that the inside is cooked perfectly.

9. Cooling: After the steaming process, chill outside the room for about 2 hours then put it in the refrigerator.

10. Melting the panir: In the 9th stage, the nuggets are ready to be wrapped in egg and flour.

11. Frying: After being wrapped in flour, the nuggets are ready to be fried with a stable temperature and low heat so that they cook evenly

\section{RESULTS AND DISCUSSION}

\subsection{Results of Expert Panelist Organoleptic Test}

The overall results of the organoleptic test on the nuggets of red dragon fruit skin, totaling 3 trained panelists, consisted

of 4 assessment parameters, namely: color, aroma, texture, taste, preference (Overall), and having a different rating scale was very fond (5), really like (4), like (3), rather like (2), neutral (1), dislike (0). The organoleptic test of this expert panelist is the first step so that researchers can improve the product and find out the deficiencies of the product related to red dragon fruit skin nuggets. In this step, the researchers made 3 samples with different concentrations, namely the first formula nuggets without dragon fruit skin, the second formula nuggets with dragon fruit skin with the same ratio of 250 grams and the third nuggets with 375 grams more dragon fruit skin. In the following figure will be presented the results of the organoleptic trial data of expert panelists.

\section{Color}

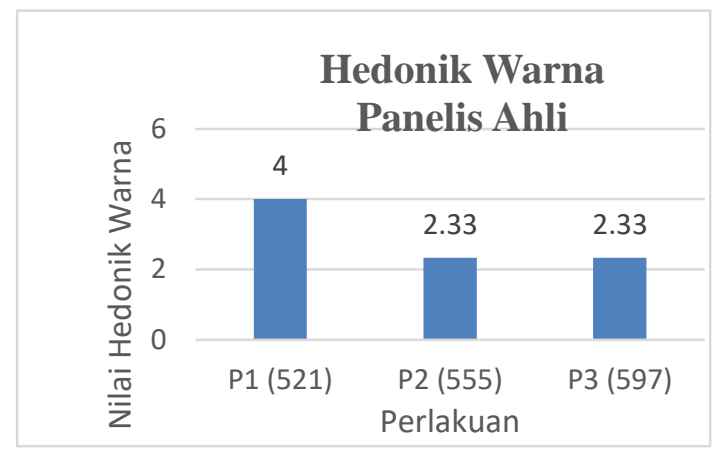

Figure 1 Panelist Organoleptic Test for Color Parameters

In Figure 4.1 it can be seen that 3 of the expert panelists who gave an assessment of the red dragon fruit skin nugget color parameter found that in the 1st treatment with code 521 the average preferred with a value of 4 or in the like range while the 2 nd and 3 rd treatments were in the range somewhat like and neutral.

Panelists' preference level was tested to show whether or not there was a difference between the three treatments / formulas using the Friedman test. In the Friedman test, it is known that the $p$-value of $0.150>0.05$ indicates that the three formulations do not significantly differ on panelist acceptance.

\section{Aroma}

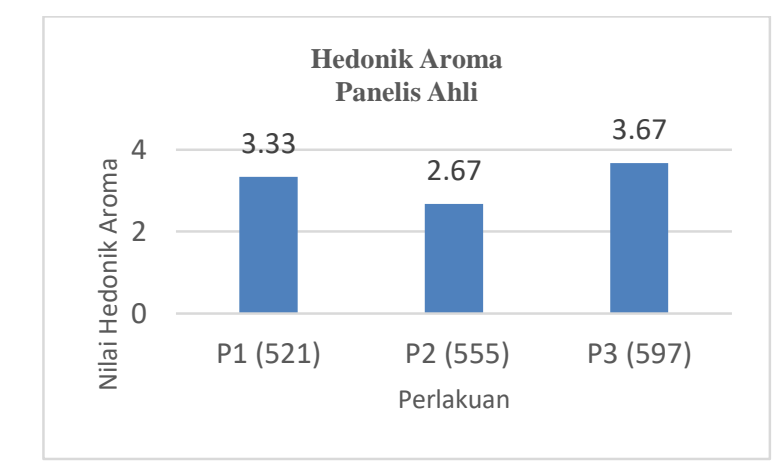

Figure 2 Organoleptic Test of the Expert Panelist of Aroma Parameters

The results of the data show that the third treatment $(\mathrm{P} 3)$ forms the treatment with the highest average value of 3.67 or is in the 
range of likes and likes. Treatment (P2) became the treatment with the lowest average value, namely 2.67 , including in the neutral range and somewhat like it. Panelists thought that researchers should pay attention to the temperature of the frying pan because it affects the aroma of the nuggets, it could be stinging and there could be no aroma. Whereas for treatment $2(\mathrm{P} 2)$ has an average value of 2.67 and occupies the range somewhat like and net. The level of preference for the panelists was tested to show whether or not there was a difference between the three treatments using the Friedman test. In the Friedman test, it is known that the p-value is $0.360>0.05$, there are three formulations with no significant difference in panelist acceptance

\section{Texture}

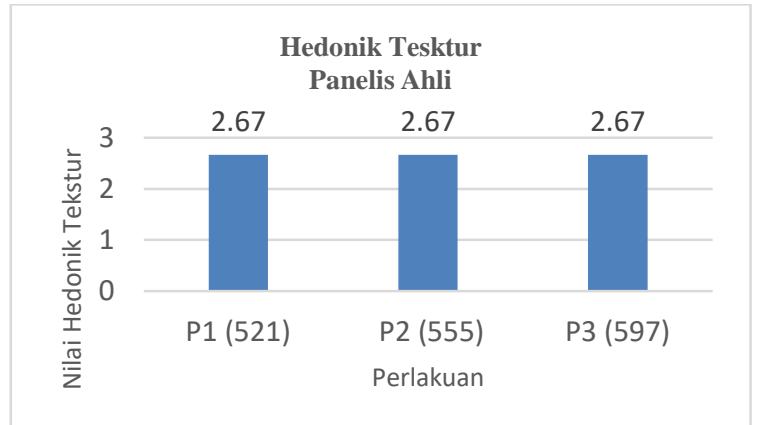

Figure 3 Organoleptic Test of Expert Panelists on Texture Parameters

In presenting the data above, the three textures favored by expert panelists have the same average value, namely 2.67, which is in the somewhat like and neutral range. The results of the Friedman test to determine the texture of red dragon fruit peel nuggets, namely the p-value of $0.368>0.05$, showed that the three formulations had no significant difference in panelist acceptance.

\section{Taste}

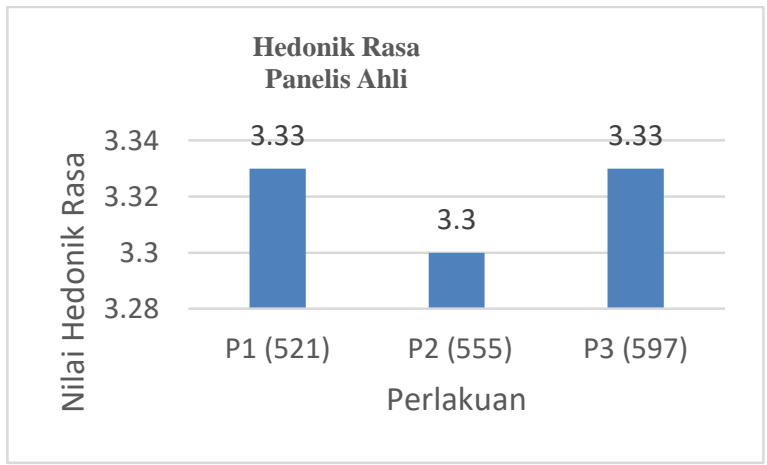

Figure 4 Organoleptic Test of Expert Panelists for Taste Parameters

In the taste assessment parameters of the expert panelists indicated that

The first treatment $(\mathrm{P} 1)$ and treatment $3(\mathrm{P} 3)$ have the same value, namely 3.33 so that they have a somewhat like and like range. While the second treatment (P2) has an average value of 3.3, which has a somewhat like range. In this taste parameter, the panelists said that you should pay attention to the frying temperature and the formula for adding spices not to be too salty. In the Friedman test, it was found that the p-value was $0.905>0.05$, indicating that the three formulations had no significant difference in panelist acceptance.

\section{Overall}

Based on the overall assessment of the product, it can be concluded that the first treatment formula, namely code 521 , can be seen in fig 5 .

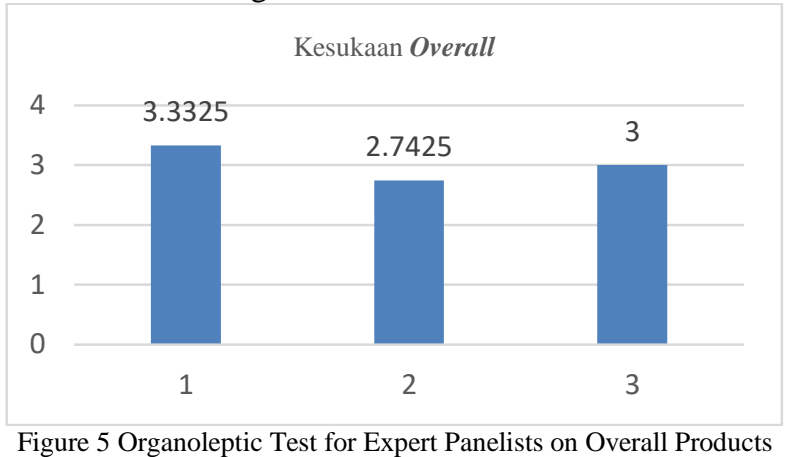

Based on the overall assessment of the product, it can be concluded that the first treatment formula, namely code 521, gets the highest average of 3.33 compared to other formulas. Whereas in the second formula, the lowest average value is 2.74 or on a neutral scale. Nugget without additional red dragon fruit peel is the best formulation based on expert panelist data.

The level of preference for the panelists who are expert on the overall product with the addition of red dragon fruit skin is tested to be tested to show whether or not there is a difference between the three formulations using the Friedman test. In the Friedman test it is known that the p-value of 0.673> 0.05 shows that there is no significant difference in panelist acceptance.

\subsection{Overall Results of Panelists' Trial Not Experts}

Presented the overall results of the organoleptic test assessment of the red dragon fruit peel nugget with 30 unskilled panelists consisting of 4 assessment parameters, namely: color, aroma, texture, taste, preference (Overall), and has a different rating scale that is very like (6), very much like (5), like (4), rather like (3), neutral (2), dislike (1). This unskilled panelist is the second or final step. In this step the researchers made 3 samples with different concentrations, namely the first formula nuggets without dragon fruit skin, the second formula nuggets with dragon fruit skin with the same ratio of 250 grams and the third nuggets with 375 grams more dragon fruit skin. In the following figure will be presented the results of the organoleptic trial data of the unskilled panelists 


\section{Color}

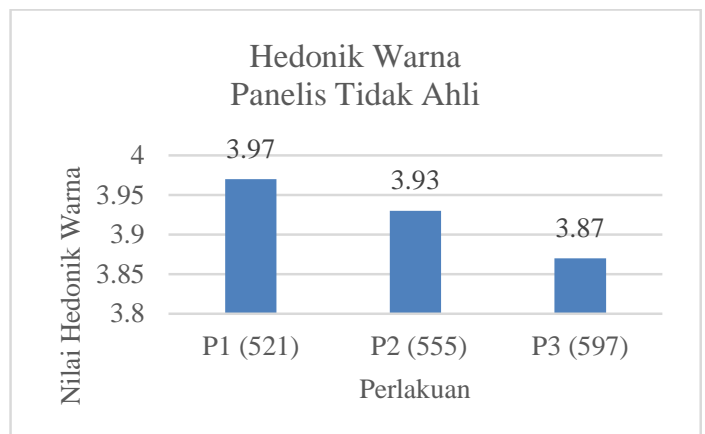

Figure 6 Panelist Organoleptic Test Not Expert on Color Parameters

The color parameter is something that can be seen for the first time by the panelists' senses. Determination of the quality of food or products is generally seen from the color of the food they have. The colors that were not so distorted gave their own impression for the panelists' research (J. K. Negara et al: 2016). The skin of dragon fruit becomes agricultural waste which contains natural dyes, namely high anthocyanins. These anthocyanins act as natural red dyes for food and can be used as a synthetic natural dye which is more guaranteed for health, anthocyanins are red pigments in plants (Abbas, 2003). In Figure 4.6, the organoleptic test of untrained panelists for color parameters shows that of the 30 panelists who gave an assessment of the red dragon fruit skin nuggets, it was found that the treatment of formula 1 (P1) had a higher average value than the 2nd and 3rd treatments, namely 3,97 in the like and somewhat like range, while the 2nd and 3rd treatments are in the like and somewhat like range

The level of preference P1, P2 and P3 were tested to determine whether or not there were differences between the three formulation treatments using the Friedman test. In the Friedman test it is known that the p-value of $0.698>0.05$ shows that the three formulations do not show a significant difference in panelist acceptance.

\section{Aroma}

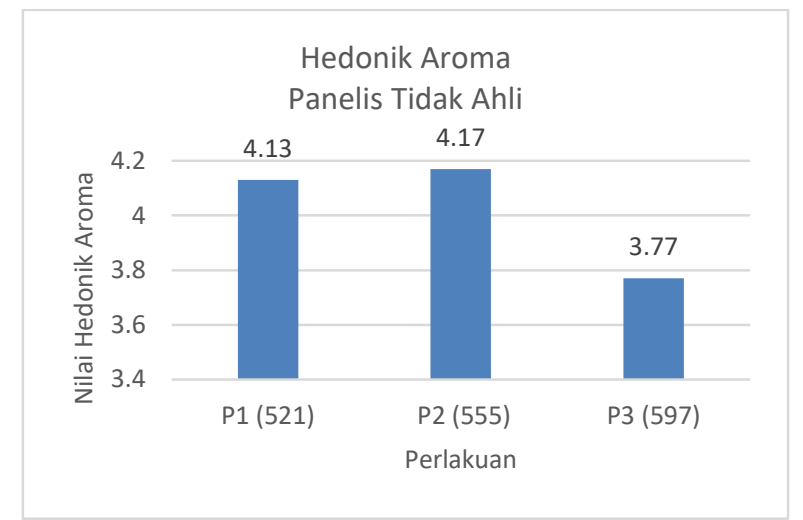

Figure 7 Orgaoleptic Test Panelists are not experts on aroma parameters
The resulting aroma is an odor caused by chemical stimulation of the ingredients of the product which is smelled by olfactory nerves in the nasal cavity. (Mulyadi, et al 2013: 290). In the diagram above of 30 unskilled panelists who have given an assessment of treatment $1(\mathrm{P} 1)$, treatment $2(\mathrm{P} 2)$ and treatment 3 (P3) it is found that the nuggets with the formulation of 250 grams of dragon fruit skin are equivalent to the composition of 250 grams of oyster mushrooms, namely the second treatment. What panelists like is not expert with a value of 4.17 and has a range of likes and likes. While the results of the third treatment got the lowest score, namely 3.77 , which has a range between like and somewhat like it, this is a sign that the more red dragon fruit skin is added, the less aroma is made.

The level of preference for treatment panelists 1, P2 and P3 was tested to determine whether or not there were differences between the three formulation treatments using the Friedman test. In the Friedman test, it was found that the pvalue was $0.924>0.05$, indicating that the three formulations did not show a significant difference in panelist acceptance.

\section{Texture}

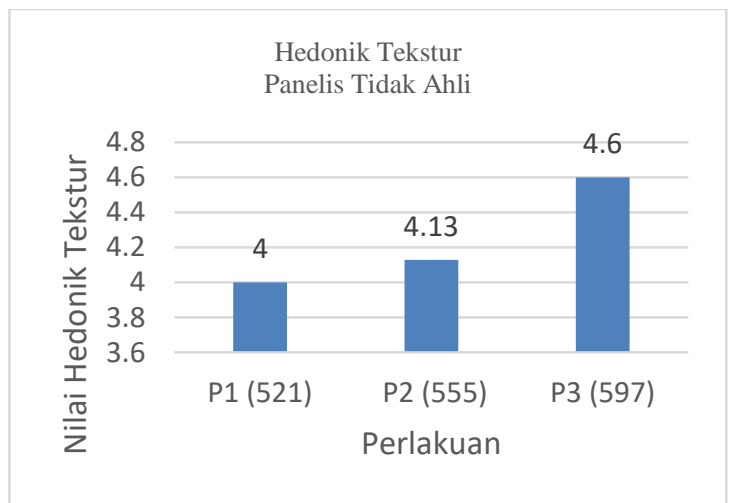

Figure 8 Panelist Oleptic Organs Test for Experimental Parameters of Texture

Texture is a characteristic of a material that is a risk combination of several physical properties including size, shape, quantity, and the elements of the material that can be felt by the senses of taste and touch, including the sense of mouth and sight (Dedy and Sudarminto, 2014: 265). In Figure 4.8 the organoleptic test of the unskilled panelists shows that the third treatment is the most preferred, namely with a value of 4.6 in the range of likes and likes while the second treatment with a value of 4.13 is in the range of likes and likes and in treatment 1 the texture parameter is The composition does not use dragon fruit peel with a value of 4 , namely the like range, this is because it is influenced by the raw materials used by the researcher.

The level of preference for treatment panelists P1, P2 and P3 was tested to determine whether or not there were differences between the three formulation treatments using the Friedman test. In the Friedman test, it is known that the p-value is $0.068>0.05$, indicating that the three formulations do not show a significant difference in panelist acceptance. 


\section{Taste}

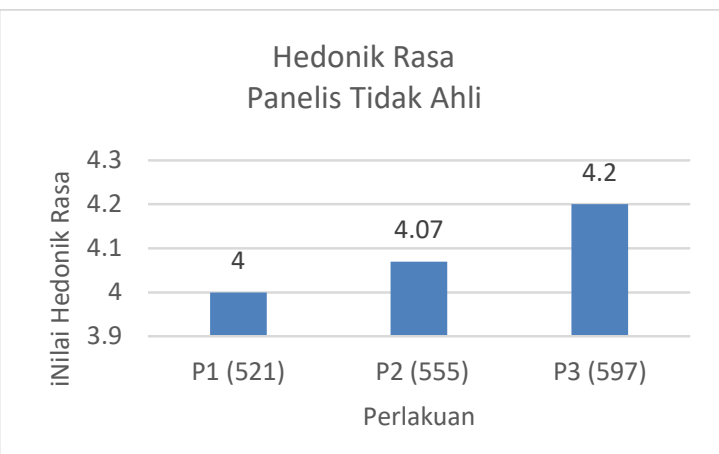

Figure 9 Panelist Organoleptic Test of Not Experts on Taste Parameters

Taste is something that is accepted by the tongue which is an important factor in a food besides aroma, color, and texture involving more of the five senses, namely the tongue, besides that taste is influenced by several factors including chemical compounds, temperature and concentration of several other flavors (Lamusu, 2015: 13). In the diagram above, it can be seen from 30 unskilled panelists who gave an assessment of the nuggets, it was found that the 3rd treatment (P3) was the most preferred flavor formulation for the panelists with an average value of 4.2 and had a range between likes and dislikes. secondly with the second treatment the average value of 4.07 in the range of likes and likes very much. This is because the more dragon fruit skins added to oyster mushrooms will give it a more concentrated and stronger taste than not using dragon fruit peels, so that non-expert panelists prefer nuggets with dragon fruit skin.

The level of preference for treatment panelists P1, P2 and P3 was tested to determine whether or not there were differences between the three formulation treatments using the Friedman test. In the Friedman test, it is known that the pvalue is $0.55>0.05$, indicating that the three formulations do not show a significant difference in panelist acceptance.

\section{Overall}

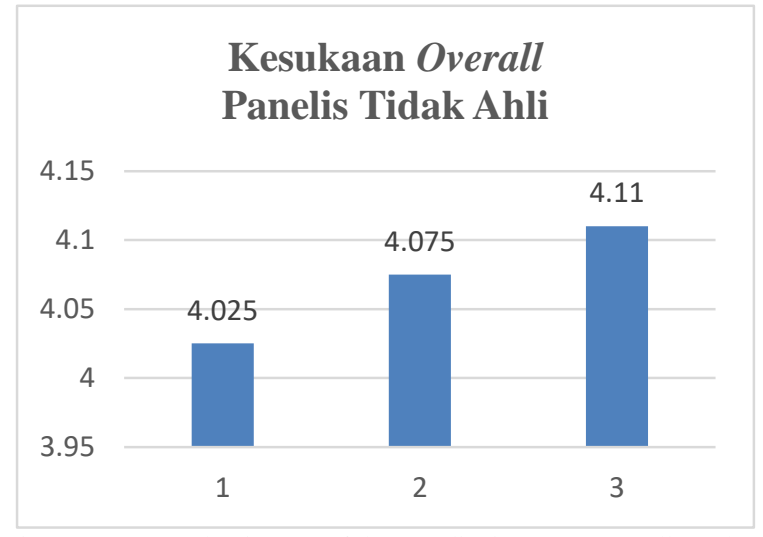

Figure 10 Organoleptic Test of the Panelist inexpert Overall Product

Based on the overall preference level of the product, it can be concluded that the 3rd treatment $(\mathrm{P} 3)$ gets the most preferred average value, namely 4.11 in the range of likes and likes very much compared to other treatments. Whereas in treatment one (P1) got the lowest score with an average of 4.025 in the like range. According to unexperienced researchers, the treatment by adding dragon fruit skin more than oyster mushrooms is the best formula and favored by the panelists. This is because the panelists prefer nuggets with dragon fruit skins that have a strong flavor image and besides that many of the panelists do not expect that dragon fruit skins that are planted in front of the house can produce food and have some pretty good nutritional content. The level of preference for treatment panelists P1, P2 and P3 was tested to determine whether or not there were differences between the three formulation treatments using the Friedman test. In the Friedman test, it is known that the p-value of 4.72>0.05 shows that the three formulations do not show a significant difference in panelist acceptance.

\subsection{Overall Product Revisions}

Pay attention to the frying temperature because it can affect the appearance of the taste of the nuggets, texture, aroma and color, nuggets that have no pan, tend to be tough, the shape of the nuggets can be improved (can be shaped according to children's tastes), pay attention to the use of the seasonings, there are variants that taste too salty ., as well as for product development, processing techniques need to be considered

\section{CONCLUSION}

\section{Studies and suggestions}

\subsection{Revised Product Review}

The development of oyster mushroom nuggets plus dragon fruit skin is intended to obtain a pulp formula that has a higher nutritional value by using natural dyes. The making of oyster mushroom nuggets is added with dragon fruit skin consisting of oyster mushrooms, skin from red dragon fruit, tofu, shrimp, onions, chicken eggs, wheat flour, salt and pepper, mashed in a certain ratio so that the appropriate formula is obtained. The consideration of selecting certain ingredients is intended so that the nutritional content of each other interacts well and complements each other's advantages and disadvantages between foodstuffs.

Oyster mushrooms were chosen because white oyster mushrooms contain a lot of protein and have a higher content than wood mushrooms in general, namely oyster mushrooms containing protein, fat, phosphorus, iron, thiamin and riboflavin higher than other types of mushrooms. Oyster mushrooms have a fast storage capacity (Arianto et al, 2009: 31-40). and choosing the skin of the red dragon fruit for natural coloring because the skin of the dragon fruit is an agricultural artificial waste containing natural anthocyanin aromatic substances that are high feasible. This anthocyanin acts as a natural red stain for food and can be used as an option as synthetic natural dyes that are more preserved for health, anthocyanins are red pigments in plants (Abbas, 2003). This can trigger a child's appetite to increase because the color is more attractive. 
It can be concluded from making oyster mushroom nuggets using red dragon fruit skin, getting three formulas with formula one not using additional dragon fruit skin as a control, formula two adding dragon fruit skin 250 grams is the same as oyster mushrooms and the third formula adds more dragon fruit skin, namely 375 grams . The overall results of the organoleptic test based on the assessment of the overall product expert panelist can be concluded that the first treatment formula, namely code 521, gets the highest average of 3.33 compared to other formulas. Whereas in the second formula, the lowest average value is 2.74 or on a neutral scale. Nugget without additional red dragon fruit peel is the best formulation based on expert panelist data. This is due to paying more attention to the frying temperature between the three nugget formulas because it can affect the appearance of the nuggets, nugget texture, aroma and color of the nuggets. Based on the level of preference for the panelists who are not experts. Overall Product, it can be concluded that the 3rd treatment (P3) gets the average value of the most preferred value, namely 4.11 in the like and very like range compared to other treatments. Whereas in treatment one (P1) got the lowest score with an average of 4.025 in the like range. Making nuggets pays more attention to the use of spices and can be shaped according to children's tastes. Overall Friedman test in developing oyster mushroom nuggets plus red dragon fruit skin did not have much effect on color, texture, taste and aroma.

\subsection{Suggestions}

In order for mushroom nugget development products using dragon fruit peel additives (hylocereus polyrhizus) to be maximally utilized, it is necessary to provide some related suggestions.

1. The author suggests that in determining the product formula to be tested, it is expected that through the validation of a botanical expert first in order to know the advantages and disadvantages of the product

\subsubsection{Suggestions for Further Development}

The need for further research on the composition of oyster mushroom nuggets using more complete red dragon fruit skin additives, the need for product effectiveness testing against obesity, the need for hedonic quality tests to find out more specifics, for example the taste of mushroom nuggets plus dragon fruit skin, for example the taste of skin on nuggets such as what etc. As well as a proximate test to analyze the content of ingredients or food, especially oyster mushroom nuggets plus dragon fruit skin. As well as the need for the socialization of the skin from red dragon fruit as a natural dye.

\section{REFERENCES}

1. Abbas, A., (2003), Identifikasi dan Pengujian Stabilitas Pigmen Antosianin Bunga Kana (Canna cocciea Mill) Serta Aplikasinya pada Produk Pangan. Malang
2. Ahmad B.S, Yana S. 2018. Metode Penelitian. CV Pustaka Setia.Bandung.

3. Arianto, D. P. dan Supriyanto. 2009. Karakteristik Jamur Tiram Putih (Pleurotus ostreatus) Selama Penyimpanan. Agroteknos 20(1): 31-40

4. Biro FM, Wien M. 2010. Childhood obesity and adult morbidities. Am J Clin Nutr.; 91: 1499-1505.

5. Budiwanto, S. 2017. Metode Penelitian dalam Keolahragaan. Malang: UM Press

6. Chazali, S. Putri Pratiwi. 2010. Usaha Jamur Tiram Skala Rumah Tangga. Jakarta: Swadaya.

7. Handayani, P.A., Rahmawati, A., 2012, Pemanfaatan Kulit Buah Naga (Dragon Fruit) sebagai Bahan Pewarna Alami Makanan Pengganti Pewarna Sintetis, Jurnal Bahan Alam Terbarukan, Volume 1, No. 2, 19-24

8. J.K. Negara, A.K dkk, 2016. Aspek Mikro Biologis Serta Sensori (Rasa, Warna, Tekstur, Aroma) pada Bentuk Penyajian Keju yang Berbeda. Vol. 04 No. 2 Halaman 286-290

9. Kementerian Kesehatan RI. 2013. Riset Kesehatan Dasar Jakarta: Kementerian Kesehatan RI; 2013

10. Mulyadi, A. F., Malingan, JM., Wignyanto \& Hermansyah R 2013. Karakteristik Organolepyik Serbuk Perisa Alami Dari Cangkang Rajungan (Portunus pelagicus) : Kajian Konsentrasi Dekstrin dan Suhu Pengertian. Jurnal Teknologi Pertanian, 14(3), 183 - 192.

11. L. Jayanti and M. Muksin, "Analisis stakeholder dalam agribisnis nuah naga di Kecamatan Bangorejo Kabupaten Banyuwangi,” J. Ilm. Inov., vol. 15, no. 3, pp. 99-107, 2015.

12. Purwaningrum S,Yuniar Wardani. 2012. Hubungan antara Asupan Makanan dan Status Kesadaran Gizi Keluarga dengan Status Gizi Balita di Wilayah Kerja Puskesmas Sewon 1 Bantul. Jurnal kesehatan masyarakat vol.6 No,3

13. Lamusu, D. 2015. Uji Organoleptik Jalangkote Ubi Jalar Ungu (Ipomoea batas 1) Sebagai Upaya Diversifikasi Pangan. Jurnal Pengolahan Pangan. 3(1), 9-15:144-211

14. Santoso, A. 2011. Serat pangan (Dietary fiber) dan manfaatnya bagi kesehatan.Jurnal Magistra. Vol 2: 3540

15. Semuel,H ,2005, Respon Lingkungan Berbelanja Sebagai Stimulus Pembelian, Jurnal Manajemen dan Kewirausahaan,Vol.7, No.2,September 2005:152-170 